\title{
Responsive Middle Level Teacher Education: Learning from Central Alberta Middle School Leaders
}

\author{
Julia Rheaume ${ }^{1, *}$, Jim Brandon ${ }^{2}$, J. Kent Donlevy², Dianne Gereluk ${ }^{2}$ \\ ${ }^{1}$ Red Deer College, Alberta \\ ${ }^{2}$ University of Calgary, Alberta \\ *Corresponding author: julia.rheaume@gmail.com
}

Received May 14, 2019; Revised June 16, 2019; Accepted July 02, 2019

\begin{abstract}
This instrumental case study examined the perspectives of 43 middle school administrators on effective middle level education to inform the evolution of a teacher education program in central Alberta, Canada. Analysis of data gathered through an online survey and focus group interviews yielded three merged findings on salient elements of the middle school concept and the key competencies required of effective beginning middle level teachers, including: (a) teaming and developmentally responsive practices are deemed essential middle school concepts; (b) effective beginning middle school teachers should demonstrate professional knowledge and skills, including the ability to create learner-centred, inclusive environments; and (c) effective beginning middle school teachers should possess certain dispositions, especially those that promote positive, productive relationships. These findings and the implications arising from them are contributing to the evolution of the teacher education program at Red Deer College and may be of benefit to teacher educators seeking to develop more responsive programming in other settings.
\end{abstract}

\section{Keywords: beginning teacher effectiveness; teacher education, learner-centered}

Cite This Article: Julia Rheaume, Jim Brandon, J. Kent Donlevy, and Dianne Gereluk, "Responsive Middle Level Teacher Education: Learning from Central Alberta Middle School Leaders." American Journal of Educational Research, vol. 7, no. 7 (2019): 445-454. doi: 10.12691/education-7-7-3.

\section{Introduction}

What competencies are school administrators looking for when hiring beginning middle level teachers? This was one of two central questions that drove our examination of school administrator perspectives on effective middle level education and was a significant component of the design process informing the development of a new B.Ed. degree at Red Deer College (RDC) in central Alberta, Canada. In addition to insights from the larger study [1], upon which this article is based, the redesign process is also benefitting from thoughtful consideration of recent research on such areas as teacher education, quality teaching, and teacher quality. Survey and focus group interview data for this article were drawn from Rheaume's [1] doctoral study, which engaged 43 school administrators from three local school districts in instrumental case study research. The purpose of this article is to garner school administrator insights on salient elements of the middle school concept as well as their views on the key competencies required of effective beginning middle level teachers.

Beginning teachers often have difficulty applying the knowledge and skills gained during teacher education to their initial classroom realities [2,3,4]. An Alberta Teachers' Association (ATA) report claimed that "the theory-to-practice gap has not yet been bridged in Alberta"
([5], p. 30). Better alignment between teacher education and current needs and realities of the K-12 school system can perhaps reduce early career attrition. As noted in the ATA [5] study on beginning teachers, "the quality of pre-service preparation has an impact on attrition" (p. 7). In the Alberta Education [6] annual report, 36\% of Albertan principals indicated that graduates of teacher education programs were inadequately prepared to become teachers. Furthermore, 25\% of beginning teachers in Alberta leave the profession within five years [7]. The Task Force for Teaching Excellence [8] identified three areas of concern pertaining to pre-service teacher education: (a) admission into programs, (b) practicum opportunities for student teachers, and (c) the alignment of teacher preparation programs with provincial vision and goals. The message is clear: there is room for improvement when it comes to preparing teachers for contemporary classroom practice.

While other scholars have focused on teacher education program design [4], the integration of theory and practice [9], or the quality of the practicum experiences [2], this study focused on the realities of local classroom contexts that graduates of the middle level teacher education program were likely to enter. Inquiry into the teaching competencies most sought-after by the middle school administrators could then inform the theoretical knowledge, essential skills, and desirable dispositions to be emphasized in the teacher education program. For the 
purposes of this article, middle level pertains to young adolescents (aged 10 to 15) and middle school refers to an educational institution between elementary and high school of varying grade configurations, most commonly grades 6 to 8 , that strives to foster the academic and personal development of all middle level learners.

The paper unfolds in six parts, beginning with a short description of the central Alberta context. An overview of the conceptual framework that situates the study in the relevant research literature is followed by an outline of the instrumental case study research design. In the results section, three research findings are presented along with their implications for middle level teacher education in central Alberta. The discussion and concluding sections shed light on ways in which the larger themes may inform the evolution of teacher education at RDC and may be transferable to teacher education in other settings.

\section{Middle Level Education in the Central Alberta Context}

Alberta's school system serves the province's 606,627 students in 1868 schools organized into 62 school jurisdictions [6]. The system employs 41,000 full and part-time teachers, each of whom is professionally prepared and provincially certificated in accordance with the provincial Teaching Quality Standard (TQS) [10,11]. Individuals seeking to become teachers need to have a Bachelor of Education degree or possess another recognized degree supplemented by completion of a teacher education program leading to a provincially approved Interim Professional Certificate. In addition to their university level teacher education, teachers are only eligible for permanent certification on the recommendation of their school superintendent following two full years of successful teaching.

Middle schools and middle level teacher education programs are uncommon in Alberta. The province has 840 junior high schools (grades 7 to 9), but only 22 middle schools in the grades 5 to 8 configuration (Alberta Education, Nov. 7, 2018). Whereas middle schools make up $11 \%$ of all schools in the central Alberta region, only 2.5\% of all schools in the province are middle schools.

The Middle Years program at RDC is offered in collaboration with the University of Alberta and is the only middle level teacher education program in the province. This unique program offers an elementary (generalist) degree with a focus on grades 4 to 9 curriculum, accepts a cohort of 40 students annually, promotes the middle school concept based on the National Middle Schools Association's (NMSA) guiding document, This We believe: Keys to Educating Young Adolescents (2010), and works closely with school districts in the region. Almost all RDC faculty members in this program have taught in local school districts and most have strong affiliations with school staff members. These connections provide reciprocal benefits. For example, pre-service teachers observe, complete practica, conduct servicelearning projects, and volunteer in nearby schools. They learn alongside experienced middle school educators in a variety of authentic contexts.

The new B.Ed. degree program design at RDC is being informed by planned shifts in provincial curriculum (from a grade 7 to 9 organization to a grade 5 to 9 configuration), the larger research study upon which this article was based [1], and a plethora of additional research. Another important design focus for the new B.Ed. degree is alignment with the revised Teaching Quality Standard (TQS), which provides a "framework for the preparation, professional growth, supervision and evaluation of all teachers” ([12], p. 2).

\section{Conceptual Framework}

The purpose of this inquiry was to gain insights into school administrator perspectives on effective middle level education to inform teacher education programming. More specifically, the intents were to understand: (a) which elements of the middle school concept are deemed essential; and, b) what competencies are required to be an effective beginning middle level teacher. In keeping with the requirements of case study research $[13,14,15,16]$, multiple sources of evidence were gathered and analyzed through survey and interview questions aligned with the two research purposes and supported with relevant and related research literature conceptualized in four parts as presented in Figure 1. These include: (a) responsive and research-informed teacher education; (b) competency frameworks for effective teaching; (c) effective middle level teaching, based on the middle school concept; and, d) middle school contexts that provide practica and hire beginning middle level teachers.

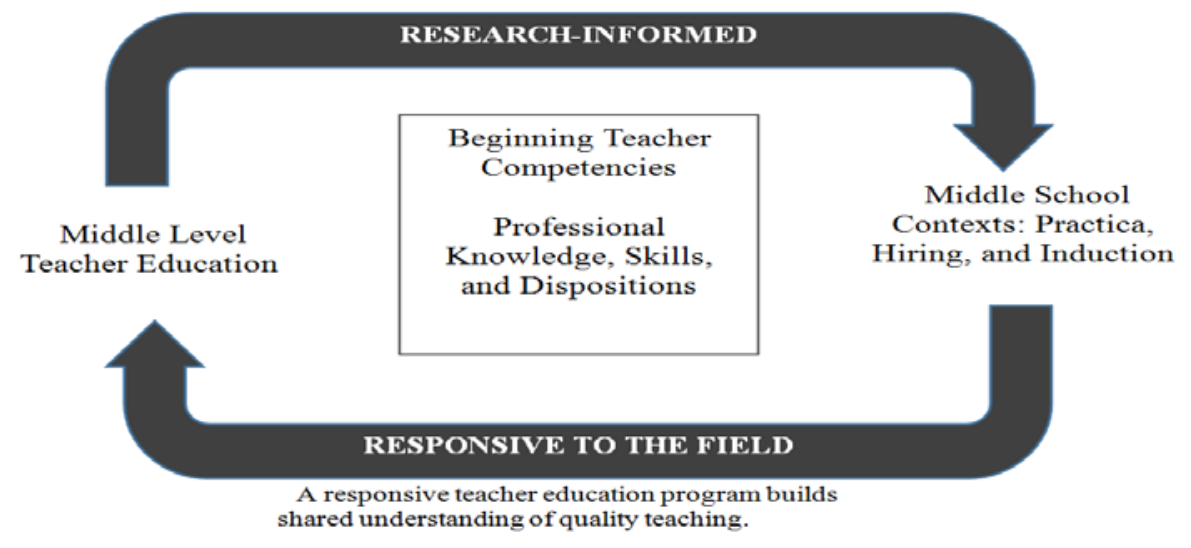

Figure 1. Research-Informed and Responsive Teacher Education 


\subsection{Responsive and Research-Informed Teacher Education}

Teacher education programs in Canada are guided by a variety of goals designed to build beginning teachers' ability to scaffold student learning in a rapidly changing contemporary world. Such intentions are derived from a number of sources, including provincial teacher certification standards, educational research, and demographic shifts [17]. Grant [18] suggested that successful programs consider these goals along with the experiences and the nature of prospective teachers to develop an array of teacher capacities: specifically, teacher knowledge, skills, and dispositions.

Many Alberta teacher education programs are adaptively implementing approaches informed by contemporary studies in teaching and learning, recent research on teacher education, and close connections with local school systems. In such settings pre-service teachers are supported through research-informed and responsive teacher education programs that generate a well-prepared and professional "community of teachers that reflects the diverse communities they serve, with a range of backgrounds and experiences, so they can connect deeply with students” ([19], p. 31).

In their seminal report, Preparing Teachers for a Changing World: What Teachers Should Learn and Be Able to Do, Darling-Hammond and Bransford [20] built on recent studies of learning to understand the cognitive, emotional, and social processes that result in the most effective learning and to use this knowledge within the design of curriculum, teaching, and assessment so that people learn more deeply and effectively. Bransford, Darling-Hammond and LePage [19] offered a three-part conceptual framework that organized "the vast amounts of information relevant to effective teaching and learning” in "three general areas of knowledge, skills, and dispositions" (p. 10) that are important for any teacher to acquire. These general areas included:

- knowledge of learners and how they learn and develop within social contexts;

- conceptions of curriculum content and goals: an understanding of the subject matter and skills to be taught in light of the social purpose of education; and,

- an understanding of teaching in light of the content and learners to be taught, as informed by assessment and supported by classroom environments. (p. 10)

Brandon [21] found that "preparing excellent teachers involves connected, evidence informed, and researchactive teacher learning in both university and school settings" (p. 163) and that field placements need to be carefully selected so that pre-service teachers learn with practitioner experts in learning enriched schools (p. 164). Hammerness and Darling-Hammond [22] captured the wisdom of learning about practice in practice:

Whereas in the traditional undergraduate program, student teaching was often placed at the end of the program, as a kind of culminating experience, many programs are now entwining carefully designed clinical experiences early and throughout a program. Many teacher educators argue that student teachers see and understand both theory and practice differently if they are taking course-work concurrently with fieldwork. (p. 401)

Close connections and collaboration with local school systems, and building shared understanding of teaching quality, are essential components of responsive teacher education programs.

\subsection{Competency Frameworks for Effective Teaching}

The Task Force for Teaching Excellence [8] called for more "flexible, innovative, and learner-centered" teaching with a shift in the role of the teacher from "that of a knowledge authority to an architect of learning - one who plans, designs, and oversees learning activities” (p. 10). Acting on their survey data, which indicated that $80 \%$ of participants (including $70 \%$ of teacher participants), were in favour of one common, province-wide practice standard for teachers, the Task Force recommended that the TQS [10] be updated (p. 28).

As the competency framework that details the expectations for all teachers in Alberta, the revised TQS [11] is similar to other professional practice standard documents widely used in the English-speaking world. In addition to the TQS, three other frameworks are examined here. Danielson [23,24] and Hattie [25] are addressed in this sub-section. Howell, Cook, and Faulkner's [26] framework that specifically addresses middle level teaching is presented in the next sub-section.

The distinction between effective teaching and effective teachers is important to keep in mind. Teacher quality (effective teachers) involves "the bundle of personal traits, skills, and understandings an individual brings to teaching, including dispositions to behave in certain ways," whereas, teaching quality (effective teaching) is having teachers who provide instruction that "meets the demands of the discipline, the goals of instruction, and the needs of students in a particular context” ([27], p. 3). Teaching quality is a vital subset of what constitutes a quality teacher. These views are in keeping with the revised 2018 TQS, which is stated as follows:

Quality teaching occurs when the teacher's ongoing analysis of context, and the teacher's decisions about which pedagogical knowledge and abilities to apply, result in optimum learning for all students. ([11], p. 3)

"All Alberta teachers are expected to meet the Teaching Quality Standard throughout their careers” ([11], p. 3). The TQS is described by the following six competencies:

1. Fostering Effective Relationships,

2. Engaging in Career-Long Learning,

3. Demonstrating a Professional Body of Knowledge,

4. Establishing Inclusive Learning Environments,

5. Applying Foundational Knowledge About First Nations, Metis and Inuit, and

6. Adhering to Legal Frameworks and Policies.

The TQS definition of competency is: "an interrelated set of knowledge, skills and attitudes, developed over time and drawn upon and applied to a particular teaching context to support optimum student learning” ([11], p. 3). Within the TQS comprehensive competency framework for effective teaching in Alberta, each of the six competencies is further described by a number of possible indicators. 
Enhancing Professional Practice: A Framework for Teaching, Charlotte Danielson's 1996 book (updated in 2007) and related online resources are widely used. In fact, the Framework serves as official government standards in a number of American states. It is flexible enough to be used in a variety of contexts, levels, and content areas. Teacher knowledge, skills, and dispositions are categorized into four domains: (a) Planning and Preparation, (b) the Classroom Environment, (c) Instruction and (d) Professional Responsibilities. A more current version, The Framework for Teaching: Six Clusters Supporting High Level Learning (draft, 2016) identifies 22 components that contribute to effective teaching. Many aspects of Danielson's framework are similar to Alberta's TQS.

Hattie [25] provided important insights into effective teaching in Visible Learning for Teachers [25]. Based on his ground breaking meta-analyses [25,28], he identified the 42 most successful interventions that differentiate between expert and experienced teachers. To Hattie, inspired and passionate expert teachers: (a) solve instructional problems, (b) interpret events in progress, (c) are sensitive to context, (d) monitor learning, (c) test hypotheses, (d) demonstrate respect for all in the school, (e) show passion for teaching and learning, and (f) help students to understand complexity (pp. $30-31$ ). Hattie's description of effective teachers takes into account context, knowledge, skills, and dispositions as noted above in Darling-Hammond's description of quality teaching and teachers.

\subsection{Effective Middle Level Teaching}

Wiliam [29] cautioned that it is "difficult and perhaps impossible to entirely disentangle teacher quality from teaching quality” (p. 30), and focused on teacher effectiveness as the means to improve student achievement. When considering effective teaching, it is important to keep the teaching context, in this case middle schools, in mind. Since their inception, middle schools were intended to ensure both the "academic and personal development of every young adolescent” ([30], p. 4) through the implementation of the middle school concept. The most widely accepted vision of the current middle school concept, This We Believe, [30] identifies four essential attributes of successful middle schools: developmentally responsive, challenging, empowering, and equitable education. The middle school concept is also comprised of distinct characteristics related to curriculum, instruction and assessment; leadership and organization; and culture and community.

While many teaching competency frameworks focus on what a teacher needs to know and do to be effective, dispositions are concerned with a teacher's way of being or nature. Disposition influences a teacher's interactions with others and their view of their students, their role, and themselves [26]. Important middle level teacher dispositions include having a positive attitude, respecting individual differences, believing that all students can succeed, and building relationships [26]. Middle level teachers need to be keenly responsive to the unique physical, social, and cognitive developmental needs of early adolescent students [31]. Developmental responsiveness influences how teachers interact with students, design instruction, and conduct assessment [32].

Howell et al. [26] indicated that, "good teaching starts with a caring, student-centred individual who can then develop a rigorous educational experience where children achieve success” (p. 13). This claim runs parallel to the finding from Anfara and Schmid's [33] review of the research on characteristics of effective middle grade teachers. Such teachers "have positive self-concept, display optimism, show enthusiasm, exhibit a good sense of humour, demonstrate flexibility, respect and accept others, are good listeners and communicators, cooperate with others” (p. 58).

The distinguishing characteristics of effective middle level teachers include being responsive and enthusiastic, possessing strong communication skills and being able to establish caring, respectful relationships. Several of these attributes are referenced in the OECD [34] Teachers Matter report:

Teacher characteristics that are harder to measure, but which can be vital to student learning include the ability to: convey ideas in clear and convincing ways, create effective learning environments for different types of students, foster productive teacher-student relationships, be enthusiastic and creative, work effectively with colleagues and parents (p. 6).

Hull [35] claimed: "Good teaching is as much about being as it is about doing” (p. 24). Effective middle level teaching requires effective teachers with just the right "know, do, be" attributes that are well-suited to working with young adolescents. Not all effective teaching frameworks discussed here paid equal attention to what teachers should know, do, and be. Whereas all frameworks highlighted the professional "know and do" aspects of teaching such as content knowledge, instructional planning and pedagogy (TQS competency \#3), Danielson [23] did not include relationships (TQS competency \#1) in her model. However, dispositions, or ways of being, were featured by Hattie [25] who identified teachers who care as being important to effective teaching, as stated in TQS competency \#4. The Howell et al. [26] Framework for Effective Middle Level Practices aligns most closely with the TQS [11] and provides a comprehensive set of guidelines for effective teaching. As such, the TQS [11] and the Howell et al. [26] framework were mainly used to inform this study on beginning middle level teacher competencies. Based on these frameworks, effective middle level teachers should possess both professional characteristics, such as curriculum, instruction and assessment knowledge and skills (know and do), and personal characteristics (be), including a responsive, reflective disposition that enables them to foster positive relationships and establish inclusive learning environments.

\subsection{Middle School Contexts: Hiring Effective Beginning Middle Level Teachers}

The preceding sections underline the importance of both effective (quality) teaching and effective (quality) teachers when hiring novice teachers. Both the professional and the personal should be considered in 
teacher selection decisions because "it matters who the principal chooses to place in classrooms of our middle schools" ([26], p. 3). Mason and Schroeder [36] found that during the hiring process, principals initially looked at professional attributes such as grades, experience, and references but the personal attributes such as enthusiasm, appearance, confidence and communication skills, as demonstrated in an interview, were given higher significance. Principals who participated in a study conducted by Ingle, Rutledge, and Bishop [37] also looked for enthusiasm, work ethic, and motivation. However, they placed most value on caring teachers with strong teaching skills and subject knowledge who were willing to contribute to school activities. Ingle et al. [37] also highlighted how middle school principals were cognizant of how well a potential teacher would fit with the school and a particular teaching team.

Brandon [21] found wide agreement with the view that preparing excellent teachers involves the development of robust and research-informed teaching competencies linked to student learning. Ministry officials, academics, and leader practitioners were quite unified in their perspectives that excellently prepared teachers should work collaboratively, build relationships, and capably design, activate, and assess student learning. The study revealed only minor variations in what participants viewed as the technical aspects of teaching. Interestingly, all participants placed heightened importance on the research-informed, collaborative, and relational teaching competencies.

\section{Research Design}

The purpose of this study was to gain insights into school administrator perspectives on effective middle level education to inform teacher education programming. Two specific research questions guided this investigation:

1. Which elements of the middle school concept are deemed essential to effective middle level education? and

2. What competencies are required to be an effective beginning middle school teacher?

An instrumental case study research design was used to address these questions [13,14,16,38,39,40,41]. A case study is an in-depth exploration of a bounded system based on extensive data collection from multiple sources. "Bounded means that the case is separated for research in terms of time, place or some physical boundaries" ([39], p. 465). The phenomenon investigated within the bounded system of the Alberta school system in 2017 was central Alberta middle school administrator perspectives on effective middle level education. The study was conducted within the protocols of the University of Calgary Conjoint Faculties Research Ethics Board.

The data generated through an online survey, focus group interviews, field notes, and documents allowed for a rich and in-depth exploration of the research questions. Our purposive sample [42] included 25 administrators from the 10 middle schools (grades 6-8, 5-8, or 6-9) along with 47 additional administrators from K-12 and K-9 schools in the three participating central Alberta school districts. Twenty-six of the 72 school administrators completed phase one's online survey for a response rate of $36 \%$. In the second phase, 17 participants engaged in six focus group interviews. Focus group participants are identified by pseudonym for the purpose of separation of ideas and illustration of themes.

The focus group interview protocol was developed based on the research questions, the literature reviewed in the conceptual framework, and results of phase one of the study. Focus group interviews were audio-recorded and transcribed verbatim. An electronic version of the Long-Table Analysis Approach [43] was used to group and code the data within an Excel Spreadsheet. Results from both phases were integrated to provide a robust interpretation. Miles et al. [42] claimed that when quantitative data is "combined with the up-close, deep, credible understanding of complex real-world contexts that characterize good qualitative studies, we have a very powerful mix” (p. 43).

\section{Results: Three Findings with Implications for Middle Level Teacher Education}

Three findings pertaining to beginning middle level teaching competencies are presented in this section. Each finding emerged from the larger study's [1] integrated analysis of the quantitative and qualitative data in keeping with case study methods [13,14,16,39,40,41]. Each finding is presented in a separate sub-section, which situates the finding in relation to relevant middle level research literature, and links it to possible implications for middle level teacher education.

\subsection{Finding 1: Middle School Concept Knowledge}

Teaming and developmental responsiveness were more important to the administrators in this study than curriculum integration and advisory programs.

The school administrators emphasized that certain teaching competencies are needed for success in current middle school realities. Although the middle school concept as expressed in This We Believe [30] is intended to be a comprehensive approach to middle level education with all components fully implemented, this ideal is rarely achieved [44,45].

Teaming. Middle schools are often organized around collaborative teaching teams that work with a common group of students. Focus group participants provided insights into the current practices, benefits, and challenges of teaming in local middle schools. Foster explained that in his school, "our big focus is always that team" ([1], p. 90). A survey respondent also indicated that a unique feature of their school was "dyad teaching partners to maximize student-teacher relationships”. Some administrators explained that the work of the team seemed to be shifting from a curricular or planning focus to becoming more data-driven and using student results to regroup certain students using an intervention model. However, as middle schools become increasingly focused on academic achievement, it is important not to lose sight 
of the capacity of teacher teams to foster positive relationships and a positive school culture.

Developmental responsiveness. Developmental responsiveness is intended to be at the foundation of all middle level educational decisions [30,32,46,47]. This aligns with Mark's description of using a developmentally appropriate lens to view everything at the middle level, from academics to extracurricular activities [1]. Some administrators recognized that middle school teaching teams are uniquely positioned to meet a wide range of student needs as they work collaboratively to foster growth in all areas of young adolescent development.

Advisory. The data revealed that few middle schools in the region currently have advisory programs designed to advocate for individual student needs. Mark's statement that "we used to have formalized advisory," ([1], p 173) and Maggie's revelation that "we have formal advisory but, I would say, it is not true to the concept of advisory as much as it is a homeroom period," ([1], p. 173) reflect limited implementation of this middle school concept in the central Alberta region. The decline of this component of the middle school concept has been attributed to increased emphasis on academic achievement, high-stakes exam preparation, and classroom teachers striving to meet individual student needs [45]. In the few existing advisory programs described in the focus group interviews, the purposes were related to building relationships, character education, and promoting school culture.

Implications for middle level teacher education. Competent middle level teachers should understand the importance of teaming and developmentally responsive practices. Familiarity with curriculum integration and the role of advisory programs is also recommended, although of lesser importance. This implies that courses on adolescent development and developmentally responsive practices, pertaining to both curriculum and instruction, should be central to middle level teacher education. A further implication is that middle level teachers should develop collaborative skills and an ability to be a productive team member during their pre-service teacher education. The cohort model combined with expectations of collaborative teamwork throughout the program was noted as a strength by Stephanie, a focus group participant and Middle Years program alumna. This finding also provides insight into current middle school practices in the central Alberta region, which can serve as a means for administrators to gauge practices in their middle schools.

\subsection{Finding 2: Professional Knowledge}

Middle level teachers should be able to meet a wide range of student needs by using their professional knowledge and skills to create learner-centred, inclusive environments.

Although the TQS stipulates that teachers need "specialized knowledge of the subject areas they teach" ([11], p. 5), only 58\% of survey respondents chose "subject-area knowledge and competency" as very important in the professional knowledge category. Just over half of the focus group participants preferred to hire generalists, in keeping with Maggie's view: “if you're a good teacher, you can learn to teach almost anything”
([1], p. 112). Because of the team scheduling in middle schools, teachers frequently teach two or more subjects. However, a teacher may not have subject-area expertise for both. Some administrators were especially concerned about teacher subject-area expertise for the higher grade levels.

Instructional strategies and assessment. During the focus group interviews, the administrators spoke passionately about middle level teachers needing a range of instructional strategies such as project-based learning, exploratory curriculum, and technology as methods to provide engaging, interest-based, authentic learning opportunities for young adolescent learners. This corresponds to the statement from This We Believe that "students and teachers are engaged in active, purposeful learning” [30], a key to effective teaching in many teaching frameworks $[11,23,25,26,27]$. In addition to engaging students, effective middle school teachers also need to be proficient at assessment. Stephanie noted that by working with a teaching partner to develop common plans and assessments, teachers could use interventions for groups of students with similar gaps in their learning. Thus, the organizational structure of teaching teams facilitates meeting student needs in multiple ways.

Learner-centred, inclusive environments. Participating administrators described effective teaching as recognizing and being responsive to a wide range of student needs in an inclusive classroom environment. They identified learner-centred practices such as differentiation, providing students with voice and choice, and knowing each student's needs and interests. Armed with an understanding of a learner's needs, effective middle school teachers should be able to differentiate instruction and provide targeted intervention and supports. This, combined with effective classroom management skills, enables teachers to "create a positive, nurturing, safe, inclusive place for kids,” ([1], p. 120) as stated by Scott. Administrators sought to hire new teachers who could employ "classroom management strategies that promote positive, engaging learning environments," an indicator of teaching competency in the TQS ([11], p. 6).

Implications for middle level teacher education. The administrators in this study recommended that middle level teachers should possess professional knowledge related to subject-area expertise, instructional strategies, differentiation, and classroom management such that beginning teachers are able to establish learner-centred, inclusive classrooms. Their recommendations emphasized the realities of their schools and, notably, did not reference the middle school concept and related practices. The TQS [11] provides a foundation for the professional knowledge that should be taught in teacher education programs. The benefits of generalist or specialist preparation for middle level teachers needs to be examined further.

\subsection{Finding 3: Dispositions}

Effective beginning middle school teachers should possess certain dispositions, especially those that promote positive, productive relationships.

There are clear indications in the literature that teacher dispositions are related to their ability to establish positive 
and productive relationships [11,26,33,49]. Similar to Chloe's comment that "being able to adapt, and being coachable” ([1], p. 133) was very important, the administrators identified caring, adaptable, and reflective learners as the most important attributes of effective teachers.

Positive, productive relationships. Being able to foster positive, productive relationships was perceived by this set of participants to be key to effective teaching. Several administrators described how building rapport with middle school students was different than at other levels and, according to Scott, an effective middle school teacher needs to be a "masterful connector with kids" ([1], p. 137). The ability and disposition to collaborate with colleagues as a positive team member were also mentioned by several administrators (Daisy, Stephanie, Bill, Scott). Participants Michelle, Binard, and others, underlined the importance of being able to engage parents and the community as attributes of an effective middle level teacher.

Implications for middle level teacher education. Being able to relate to middle level students and being responsive to their developmental needs is an added layer of complexity for prospective middle level teachers. Building on the findings of this study, it is our position that pre-service teachers need both theoretical and practical knowledge, along with field experience to understand and enact supportive relationships with young adolescents. We also suggest that it would be advantageous for teacher education programs to provide time for reflection and opportunities for self-awareness development to foster dispositions of caring, adaptability, and a desire to learn.

\section{Discussion}

The findings that emerged from this study indicate that central Alberta middle school administrators are looking for a particular competency set in their beginning teachers that encompasses both professional knowledge and specific professional dispositions. The middle level teachers these school leaders wish to hire should be caring, adaptable, and reflective team players who employ developmentally responsive practices, design engaging learning that optimizes learning for all students, and create positive, learner-centred, inclusive environments. These findings echo those of Hatt, Maynes, and Kmiec [49], who found that administrators want teachers who have the more tangible academic and pedagogical knowledge combined with the intangible qualities that enable them to connect with their students.

Cranston [50] offered the insight that principals and their colleagues on selection panels benefit from having a clear, shared understanding of the knowledge, skills, and dispositions they deem important when hiring teachers. As Table 1 reveals, each of the four competency frameworks for effective teaching itemized in our literature review addresses several of the teaching competencies identified by school leader participants. In fact, we argue that the revised TQS [11] provides a workable framework to inform the teacher selection process in combination with several very important relational and collaborative middle school dispositions. The TQS also provides a common language and shared expectations for teacher education, and then professional growth, supervision, and evaluation once pre-service teachers become in-service teachers.

Table 1. Administrator Views in Relation to Four Competency Frameworks for Effective Teaching

\begin{tabular}{|c|c|c|c|c|}
\hline $\begin{array}{l}\text { Alberta Education [11] } \\
\text { Teaching Quality Standard } \\
\text { (TQS) }\end{array}$ & $\begin{array}{l}\text { Rheaume, et al. [1] } \\
\text { Perspectives of Central } \\
\text { Alberta Middle School } \\
\text { Administrators }\end{array}$ & $\begin{array}{l}\text { Hattie [25] } \\
\text { Visible Learning for } \\
\text { Teachers }\end{array}$ & $\begin{array}{l}\text { Howell, Cook \& Faulkner } \\
\text { [26] } \\
\text { Framework for Effective } \\
\text { Middle Level Practices }\end{array}$ & $\begin{array}{l}\text { Danielson [23] } \\
\text { The Framework for } \\
\text { Teaching: Six Clusters } \\
\text { Supporting High Level } \\
\text { Learning }\end{array}$ \\
\hline \multicolumn{5}{|l|}{4 TQS Competencies } \\
\hline $\begin{array}{l}\text { - Fostering effective } \\
\text { relationships }\end{array}$ & $\begin{array}{l}\text { - Promoting positive, } \\
\text { productive relationships } \\
\text { - Caring, adaptable }\end{array}$ & $\begin{array}{l}\text { - Passionate teachers that } \\
\text { care, control, clarify, } \\
\text { challenge, captivate, } \\
\text { confer, and consolidate }\end{array}$ & • Relationships & $\begin{array}{l}\text { - Safe, respectful, } \\
\text { supportive, and challenging } \\
\text { learning environment }\end{array}$ \\
\hline $\begin{array}{l}\text { - Engaging in career-long } \\
\text { learning }\end{array}$ & $\begin{array}{l}\text { - Collaborative teaming } \\
\text { - Reflective learners }\end{array}$ & • Build collective efficacy & $\begin{array}{l}\text { - Teacher dispositions and } \\
\text { professional behaviours }\end{array}$ & - Professionalism \\
\hline $\begin{array}{l}\text { - Demonstrating a } \\
\text { professional body of } \\
\text { knowledge } \\
\text { Designing learning } \\
\text { o Instructional strategies to } \\
\text { engage students in } \\
\text { meaningful learning } \\
\text { o Assessment }\end{array}$ & $\begin{array}{l}\text { - Developmental } \\
\text { responsiveness } \\
\text { - Instructional strategies } \\
\text { and assessment }\end{array}$ & $\begin{array}{l}\text { - Organize and use } \\
\text { content knowledge } \\
\text { - Monitor learning and } \\
\text { provide feedback } \\
\text { - Solve instructional } \\
\text { problems } \\
\text { - Interpret events in } \\
\text { progress }\end{array}$ & $\begin{array}{l}\text { - Curriculum and } \\
\text { instruction; Assessment; } \\
\text { - Content knowledge; } \\
\text { - Developmental spectrum }\end{array}$ & $\begin{array}{l}\text { - Clarity of instructional } \\
\text { purpose and accuracy of } \\
\text { content; } \\
\text { - Student intellectual } \\
\text { engagement; } \\
\text { - Successful learning by all } \\
\text { students }\end{array}$ \\
\hline $\begin{array}{l}\text { - Establishing inclusive } \\
\text { learning environments }\end{array}$ & $\begin{array}{l}\text { • Learner-centred, } \\
\text { inclusive environments }\end{array}$ & $\begin{array}{l}\text { - Optimal classroom } \\
\text { climate for learning; } \\
\text { - Passionate teachers who } \\
\text { care, control, clarify, } \\
\text { challenge, captivate, } \\
\text { confer, and consolidate }\end{array}$ & $\begin{array}{l}\text { - Classroom management; } \\
\text { • Organizational structures }\end{array}$ & $\begin{array}{l}\text { - Safe, respectful, } \\
\text { supportive, and challenging } \\
\text { learning environment } \\
\text { - Classroom management }\end{array}$ \\
\hline
\end{tabular}


One of this study's key insights is that relationships and responsiveness are at the core of being an effective middle level teacher. The ability to build relationships is as an essential attribute of effective middle school teachers. Although the professional knowledge and skills are critical, a teacher who is unable to build relationships with students may struggle to meet diverse student needs, manage a class, or establish a learner-centred environment. As Bruce said, middle school teachers "know how to make relationships with kids, and they understand that they're not going to be able to teach them anything if they don't have a relationship with them" ([1], p. 204). Given the importance of relationships, it makes sense that the administrators rated caring, a relational characteristic, as the most important disposition of effective teachers.

Responsiveness was also important to effective teaching, especially an ability to differentiate and use instructional strategies to engage learners. A teacher's ability to design learning environments to meet diverse learner needs in inclusive classrooms was viewed as a top priority. Scott described "the cognitive delays, the behaviour difficulties, the home life, all of those things that are so much more prevalent in all of our schools now" ([1], p. 124) and indicated that pre-service teachers "had no idea they'd have some of these challenges in the classrooms" ([1], p. 124). Not surprising then, administrators indicated that adaptable was a highly rated disposition of effective middle school teachers.

The priority assigned to relationships and responsiveness by study participants presents a conundrum for teacher education. If a distinguishing feature of a beginning teacher who is apt to experience success in a middle school classroom is strongly dependent upon disposition, how can teacher education programs screen for those dispositions upon admission, and foster them during the pre-service teacher education program? Without diminishing the research-informed professional knowledge acquired during teacher education programs, perhaps more concerted emphasis on professional dispositions would help address the theory-practice gap.

As pre-service teachers become more familiar with the dispositional expectations of the profession throughout their coursework and, if possible through increased exposure to the field through practicum as suggested by Desbiens et al. [2] and others, early career attrition may be diminished. Similarly, Foster recommended "more time in front of kids" ([1], p. 125) as a means to optimize preparation of pre-service teachers. This would perhaps also address Maggie's concern that pre-service teachers "are not ready for the workload" ([1], p. 129) or Binard's observation that they "are not prepared for how much work actually has to be put into lesson planning and the day-to-day actions that happen within a school” ([1], p. 128). More time in schools would likely help pre-service teachers become more attuned to the expectations of the profession. By integrating the university-based coursework with the practicum experiences as promoted by Falkenberg [9], teacher educators can guide pre-service teachers to better understand the demands of the profession while cultivating professional dispositions such as reflection and willingness to learn. It is widely agreed in the research literature that early and ongoing learning experiences in welcoming and learning-enriched school settings are key elements of strong teacher education programming $[19,22,51]$. The participants in this study supported increased access to pre-service teachers as a means to bridge the theory-practice gap.

\section{Conclusions}

This study's middle school administrator participants provided clear indications of the beginning teacher competencies they most valued, encompassing both professional knowledge and positive dispositions. Novice teacher understanding of teaming and developmentally responsive practices were deemed more important than curriculum integration and other middle school organizational structures. Providing engaging instruction and establishing learner-centred, inclusive environments were viewed as essential beginning middle level teaching competencies. Dispositions toward productive relationships were of primary importance.

The close working relationships with local school districts, familiarity with the people, the schools, and the context more generally, provided an opportunity to engage with the research participants in a synergistic, mutually beneficial manner during this study. This inquiry served to revive the discussion about middle level practices in the region, foster shared understanding related to teaching competencies, and clarify expectations of beginning teachers. Better alignment with the needs of the local school districts should mean that the beginning teachers they hire are better equipped for the school realities they encounter as they transition from pre-service to in-service teachers. This study was an example of how one teacher education program is being responsive to local stakeholder input. The results of this study are being used to inform the development of the new B.Ed. degree at RDC, which will include, for example, a focus on relationships, dispositions, and inclusion.

An examination of the practical realities of the school contexts the beginning teachers are likely to enter upon graduation can serve to inform the teacher education program in terms of which aspects to incorporate, enhance, diminish, or abolish. This does not mean to suggest that teacher preparation should be based entirely on the practical realities of current educational systems. There is certainly a role for teacher education programs to provide research-based, and theoretical understandings toward a plethora of defined goals of education. However, a grounding in practical realities can perhaps narrow the gap between post-secondary institutions and the lived realities of teaching in schools today. Through ongoing conversations and opportunities for school districts to provide feedback, programs can adjust as needed and become more responsive to shifts in regional and global educational contexts.

\section{References}

[1] Rheaume, J. G. (2018). Middle School Administrators' Perspectives on Effective Middle Level Education in Central Alberta (Unpublished doctoral thesis). University of Calgary, Calgary, AB. 
[2] Desbiens, J.-F., Gervais, C., Lepage, M. \& Correa-Molina, E. (2015). In T. Falkenberg (Ed.), Handbook of Canadian research in initial teacher education (pp. 167-182). Ottawa, ON: Canadian Association for Teacher Education.

[3] Foster, R., Wimmer, R., Winter, M., \& Snart, F. (2010). Field experiences in teacher education: What is and what could be-A case study of the University of Alberta. In T. Falkenberg \& $\mathrm{H}$. Smits (Eds.), Field experiences in the context of reform of Canadian teacher education programs (pp. 187-223). Winnipeg, MB: Faculty of Education of the University of Manitoba. Retrieved from

http://umanitoba.ca/education/TEResearch/Conference 2009.html.

[4] Russell, D., \& Dillon, T. (2015). The Design of Canadian Teacher Education Programs. In T. Falkenberg (Ed.), Handbook of Canadian research in initial teacher education (pp. 151-166). Ottawa, ON: Canadian Association for Teacher Education.

[5] Alberta Teachers' Association. (2013). Teaching in the early years of practice: A five-year longitudinal study. Edmonton: author. Retrieved from

https://www.teachers.ab.ca/SiteCollectionDocuments/ATA/Public ations/Research/Teaching in the Early Years of Practice (PD-8619b).pdf.

[6] Alberta Education. (2015). Annual report. Retrieved from https://education.alberta.ca/media/1626451/alberta_education_ann ual_report_2014-15.pdf

[7] Alberta Education. (2013). A transformation in progress: Alberta's K-12 education workforce 2012/2013. Edmonton: Government of Alberta. Retrieved from

https:/education.alberta.ca/media/6850185/transformation-inprogress-february-2013-final.pdf.

[8] Alberta Education. (2014). Task force for teaching excellence. Edmonton: Government of Alberta. Retrieved from http://open.alberta.ca/dataset/0c3c1074-b890-4db0-8424d5c84676d710/resource/1315eb44-1f92-45fa-98fd3f645183ac3f/download/ GOAETaskForceforTeachingExcellence -WEB-updated.pdf.

[9] Falkenberg, T. (2015). Introduction: Canadian research in initial teacher education. In T. Falkenberg (Ed.), Handbook of Canadian research in initial teacher education (pp. 1-16). Ottawa, ON: Canadian Association for Teacher Education.

[10] Alberta Education. (1997). Teaching quality standard application to the provision of basic education in Alberta. Edmonton: Government of Alberta. Retrieved from: https://education.alberta.ca/media/1626523/english-tqs-card2013_3.pdf.

[11] Alberta Education. (2018a). Teaching Quality Standard. Edmonton: Government of Alberta. Retrieved from https://education.alberta.ca/media/3739620/standardsdoc-tqs-_faweb-2018-01-17.pdf

[12] Alberta Education. (2018b, November 7). Shift in curriculum development to benefit students. Edmonton: Government of Alberta. Retrieved from:

https://www.alberta.ca/release.cfm?xID=6195755084622-E3AB19E2-C76C5469E33825ED.

[13] Merriam, S. (1998). Qualitative research and case study applications in education. San Francisco: Jossey-Bass Publishers.

[14] Stake, R. E. (1995). The art of case study research. Thousand Oaks, CA: Sage Publications Inc

[15] Stake, R. (2006). Multiple case study analysis. New York: The Guilford Press.

[16] Yin, R. K. (2009). Case study research: Design and methods (5 $5^{\text {th }}$ ed.). Thousand Oaks, CA: Sage Publications Inc.

[17] Brandon, J., Friesen, S., Gereluk, D., \& Nickel, J. (2016). Cultivating essential teaching capacities through researchinformed teacher education. In M. Hirschkorn \& J. Mueller (Eds.), What should Canada's teachers know? Teacher capacities: Knowledge, beliefs, and skills. Ottawa, ON: Canadian Association for Teacher Education. (Available at https://sites.google.com/site/cssecate/fall-working-conference).

[18] Grant, C. (2008). Teacher Capacity. In M. Cochrane-Smith, S Feiman-Nemser \& J. McIntyre (Eds.), Handbook of research on teacher education: Enduring questions in changing contexts ( $3^{\text {rd }}$ ed., pp. 127-133). New York, NY: Routledge.

[19] Bransford, J., Darling-Hammond, L., \& LePage, P. (2005). Introduction. In L. Darling-Hammond \& J. Bransford (Eds.), Preparing teachers for a changing world: What teachers should learn and be able to do (pp. 1-39). San Francisco, CA: JosseyBass.

[20] Darling-Hammond, L., \& Bransford, J. (2005). Preparing teachers for a changing world: What teachers should learn and be able to do. San Francisco, CA: Jossey-Bass.

[21] Brandon, J. (2015). Excellent teachers for northern and remote Alberta schools. In N. Maynes, \& B. E. Hatt (Eds.), The complexity of hiring, supporting, and retaining new teachers across Canada (pp. 150-168). Canadian Association for Teacher Education / Association canadienne pour la formation à l'enseignement. Retrieved from https://cate-acfe.ca/workingconference-publications/

[22] Hammerness \& Darling-Hammond, 2005: The design of teacher education programs. In L. Darling-Hammond \& J. Bransford (Eds.), Preparing teachers for a changing world: What teachers should learn and be able to do (pp. 390-441). San Francisco: Jossey-Bass.

[23] Danielson, C. (2016). The Framework for Teaching: Six Clusters Supporting High Level Learning (draft). Princeton, NJ: Danielson Group. Retrieved from http://www.danielsongroup.org/framework/.

[24] Danielson, C. (2007). Enhancing professional practice: A framework for teaching. Alexandria, VA: Association for Supervision and Curriculum Development.

[25] Hattie, J. (2012). Visible learning for teachers: Maximizing impact on learning. New York, NY: Routledge.

[26] Howell, P., Cook C., \& Faulkner, S. (2013). Effective middle level teaching: Perceptions on the preparedness of newly hired teachers. Middle Grades Research Journal, 8(3), 1-22.

[27] Darling-Hammond, L. (2010). Recognizing and developing effective teaching: What policymakers should know and do (policy brief). Washington, DC: Partnership for Teacher Quality.

[28] Hattie, J. (2009). Visible learning: A synthesis of over 800 metaanalyses relating to achievement. New York, N.Y: Routledge.

[29] Wiliam, D. (2016). Leadership for teacher learning: Creating a culture where all teachers improve so that all students succeed. West Palm Beach, FL: Learning Sciences International.

[30] National Middle School Association (NMSA). (2010). This we believe: Keys to educating young adolescents. Westerville, $\mathrm{OH}$ : NMSA.

[31] Howell, P. (2012). Conceptualizing developmentally responsive teaching in early field experiences. Middle Grades Research Journal, 7(4), 43-55.

[32] Thornton, H. (2013). A case analysis of middle level teacher preparation and long-term teacher dispositions. Research in Middle Level Education (RMLE) online, 37(3), 1-19.

[33] Anfara, V. A., \& Schmid, J. B. (2007). What research says: Defining the effectiveness of middle grades teachers. Middle School Journal, 38(5), 5, 54-62.

[34] Organisation for Economic Co-operation and Development (OECD). 2011. Teachers matter: Attracting, developing and retaining effective teachers, pointers for policy development. Paris, France: Directorate for Education, Education and Training Policy Division. Retrieved from https://www.oecd.org/edu/school/48627229.pdf.

[35] Hull, J. (2013). Framing a New Standard for Teaching in Alberta. Alberta Journal of Educational Research, 59(1), 17-28.

[36] Mason, R.W., \& Schroeder, M. P. (2010). Principal hiring practices: Toward a reduction of uncertainty. The Clearing House, 83, 186-193.

[37] Ingle, K., Rutledge, S., \& Bishop, J. (2011). Context matters: Principals' sensemaking of teacher hiring and on-the-job performance. Journal of Educational Administration, 49(5), 579-610.

[38] Brinkmann, S., \& Kvale, S. (2015). InterViews: Learning the craft of qualitative research interviewing (3rd ed.). Thousand Oaks, CA Sage.

[39] Creswell, J. W. (2012). Educational research: Planning, conducting, and evaluating quantitative and qualitative research (4th ed.). Boston, MA: Pearson Education Inc.

[40] Merriam, S. B. (2009). Qualitative research: A guide to design and implementation. San Francisco, CA: John Wiley \& Sons

[41] Stake, R. (2005). Qualitative case studies. In N. Denzin \& Y. Lincoln (Eds.), Sage handbook of qualitative case research (pp. 443-466). Thousand Oakes, CA: Sage Publications. 
[42] Miles, M. B., Huberman, M., \& Saldana, J. (2014). Qualitative data analysis: A methods sourcebook. Thousand Oaks, CA: Sage.

[43] Krueger, R. \& Casey, M. A. (2000). Focus groups: A practical guide for applied research $\left(3^{\text {rd }}\right.$ ed.). Thousand Oaks, CA: Sage Publications.

[44] Lounsbury, J. H. (2013). Middle level education: A chronological history and a personal perspective. In P. G. Andrews (Ed.), Research to guide practice in middle grades education (pp. 11-49). Westerville, OH: Association for Middle Level Education.

[45] Schaefer, M. B., Malu, K. F., \& Yoon, B. (2016). An Historical Overview of the Middle School Movement, 1963-2015, RMLE Online, (39)5, 1-27.

[46] Center for Collaborative Education (CCE). (2003a). Turning points: At the turning point, the young adolescent learner. Boston, MA: CCE.

[47] Center for Collaborative Education (CCE). (2003b). Turning points: School structures that support learning and collaboration. Boston, MA: CCE.

[48] McKnight, K., Graybeal, J., Yarbro, J., \& Graybeal, L. (2016). Canada: What makes an effective teacher? Series 15 of 23. In K McKnight et al., The heart of great teaching: Pearson global survey of educator effectiveness. London, England: Pearson Education, Inc. Retrieved from

https://www.pearson.com/corporate/efficacy-and-

research/schools-education-research/research-reports/globalsurvey-of-educator-effectiveness.html.

[49] Hatt, B. E., Maynes, N. \& Kmiec, J. (2015). What's wrong with getting teacher hiring right?. In N. Maynes \& B. E. Hatt (Eds.) The Complexity of Hiring, Supporting, and Retaining New Teachers in Canada. (pp. 179-194). Canadian Association for Teacher Education/Association Canadienne pour la formation à l'enseignement.

[50] Cranston, J. (2015). Navigating the Bermuda triangle of teacher hiring practices in Canada. In N. Maynes \& B. E. Hatt (Eds.) The Complexity of Hiring, Supporting, and Retaining New Teachers in Canada. (pp. 179-194). Canadian Association for Teacher Education/Association Canadienne pour la formation à l'enseignement.

[51] Hammerness, Darling-Hammond, \& Bransford, J. (2005). How teachers learn and develop. In L. Darling-Hammond \& J. Bransford (Eds.), Preparing teachers for a changing world: What teachers should learn and be able to do (pp. 358 - 389). San Francisco: Jossey-Bass.

(C) The Author(s) 2019. This article is an open access article distributed under the terms and conditions of the Creative Commons Attribution (CC BY) license (http://creativecommons.org/licenses/by/4.0/). 